\title{
TSH - Clinical Aspects of its Use in Determining Thyroid Disease in the Elderly How does it Impact the Practice of Medicine in Aging?
}

Mackenzie Deary ${ }^{1}$, Timothy Buckey ${ }^{1}$ and Offie P. Soldin ${ }^{1,2 *}$

${ }^{1}$ Georgetown University Medical Center, 3800 Reservoir Road NW, Washington DC 20057, USA

${ }^{2}$ Departments of Oncology, Medicine, Obstetrics and Gynecology, Pharmacology and Physiology, Georgetown University Medical Center, Washington DC

\begin{abstract}
The last four decades have seen enormous growth in the efficacy of serum thyroid stimulating hormone (thyrotropin, TSH) assay methodology, establishing TSH as the hallmark of thyroid testing. At the center of the considerations is the strong positive correlation between serum thyrotropin and free thyroxine concentrations. While it is widely accepted that elevated serum TSH concentrations are consistent with thyroid dysfunction, a vast multitude of additional factors must be considered before an accurate clinical diagnosis can be made followed by an appropriate treatment. Epidemiological studies have demonstrated slightly elevated serum TSH concentrations among the elderly population. There is, however, a debate whether these elevated TSH levels reflect an increased prevalence of hypothyroidism among the elderly or a normal aspect of healthy aging. A comprehensive analysis of the many variables associated with this debate and TSH measurement as a diagnostic tool in aging, should provide insight into the clinical efforts to diagnose and treat thyroid disease, particularly in the elderly population.
\end{abstract}

Keywords: Hypothyroid; Hyperthyroid; Thyrotropin; Aging; Thyroxine

\section{Introduction}

Hypothyroidism has multiple etiologies and manifestations. Consequently, appropriate treatment requires accurate laboratory analysis and clinical diagnosis. The 2012 clinical practice guidelines for the management of hypothyroidism in adults, co-sponsored by the American Association of Clinical Endocrinologists (AACE) and the American Thyroid Association (ATA), maintain that serum TSH is the single best screening test for primary thyroid dysfunction for the vast majority of outpatient clinical situations. Similar recommendations were made by the clinical guidelines of the ATA for the diagnosis and management of thyroid disease during pregnancy and postpartum for more extreme situations of thyroidal stress, such as pregnancy $[1,2]$.

Thyroid-Stimulating Hormone (TSH) is a $28 \mathrm{kDa}$ glycoprotein released from thyrotrophs in the anteromedial region of the pituitary which, in turn, stimulates thyroidal thyroxine (T4) and triiodothyronine (T3) synthesis [3]. Serum TSH concentrations can provide the most sensitive index to reliably detect thyroid function abnormalities and is the primary means of studying thyroid function [4-6]. The diagnostic superiority of TSH measurement arises principally from the inverse log/ linear relationship between circulating TSH and free thyroxine (FT4) concentrations $[4,7,8]$. This inverse log-linear relationship between FT4 and serum TSH concentrations is based on the negative hypothalamic -pituitary-thyroid feedback mechanism in which minor reductions in FT4 concentrations correlate with a logarithmic increase in serum TSH. Although TSH has been considered the most reliable indicator of thyroid function abnormalities, there are several issues that challenge current knowledge.

This review will examine potential confounding factors in the measurement of TSH, the recent controversy surrounding TSH reference intervals, genetic predisposition to particular TSH concentrations, the observed correlation between thyroid function and longevity, and the peer-reviewed literature on age-related changes in TSH in differing populations and subject sets.

\section{When TSHElevationsmay not Reflect TrueHypothyroidism}

Not all individuals with TSH elevations are hypothyroid, and therefore they would not require thyroid hormone therapy. It has been demonstrated that in individuals who are anti-TPOAb or TgAb negative, serum TSH concentration greater than $3.0 \mathrm{mIU} / \mathrm{L}$ occur with increasing frequency with aging. In the elderly over $80 \mathrm{yrs}$ of age, $23.9 \%$ had serum TSH concentrations between 2.5 and $4.5 \mathrm{mIU} / \mathrm{L}$, and $12 \%$ had serum TSH concentrations above $4.5 \mathrm{mIU} / \mathrm{L}$ [9]. Thus, very mild TSH elevations in older individuals may not reflect subclinical thyroid dysfunction, but rather be a normal manifestation of aging. This presents a dilemma: while normal TSH reference intervals, particularly for some sub-populations, may need to be narrowed $[10,11]$. The normal reference interval of TSH may need to be widened with increasing age, with the upper reference limit higher than the upper limit for younger adults. By adjusting the normal reference interval of serum TSH concentrations based on aging, unnecessary thyroid hormone therapies may be avoided [1].

In addition to the elderly, young adults with Down's syndrome have a higher prevalence of thyroid autoimmune disorders than the general population. In fact, $3 \%$ of children with Down's syndrome have overt thyroid diseases. Yet, in the same population the frequency varies from 13 to $50 \%$ of children with TSH $>10 \mathrm{mIU} / \mathrm{L}$. In general, for young adults with Down's syndrome anti-thyroid antibodies from an autoimmune disorder produce the elevated levels of TSH [12].

\section{TSH Assay Interferences}

The current standard of care calls for the use of third generation

*Corresponding author: Dr. Offie P. Soldin, Department of Oncology, Lombardi Comprehensive Cancer Center, LL, S-166, Georgetown University Medical Center, 3800 Reservoir Road NW, Washington DC 20057, USA, Tel: 202-687-4717; Fax: 202-788-3034; E-mail: os35@georgetown.edu

Received September 21, 2012; Accepted October 27, 2012; Published October 29,2012

Citation: Deary M, Buckey T, Soldin OP (2012) TSH - Clinical Aspects of its Use in Determining Thyroid Disease in the Elderly How does it Impact the Practice of Medicine in Aging? Adv Pharmacoepidem Drug Safety 1:119. doi:10.4172/21671052.1000119

Copyright: (C) 2012 Deary M, et al. This is an open-access article distributed under the terms of the Creative Commons Attribution License, which permits unrestricted use, distribution, and reproduction in any medium, provided the original author and source are credited. 
TSH assays with functional sensitivity of $<0.02 \mathrm{mIU} / \mathrm{L}[4,13-15]$, a level of sensitivity necessary for detecting degrees of TSH suppression. For example, TSH concentrations ranging between $0.01-0.1 \mathrm{mIU} / \mathrm{L}$ represent a significant risk for atrial fibrillation in older patients and are often an iatrogenic consequence of levothyroxine (LT4) suppression or an unintended result of replacement therapy $[16,17]$. Targeting the degree of TSH suppression plays a critical role in the management of thyroid cancer, and in ambulatory hypothyroid patients serum TSH concentrations are used as the target for adjusting LT4 replacement [1821]. Since thyroxine (and LT4) have a very narrow therapeutic index, TSH sensitivity can be critical, and serum TSH monitoring provides better sensitivity than does FT4 testing.

TSH assay methods vary in their susceptibility to interfering substances [22]. A physician may suspect assay interference when a reported value is inconsistent with the clinical status of a patient. Clearly, without such a request it is difficult for a laboratory to proactively detect assay interference from a single measurement, such as an isolated TSH test. The most practical way to investigate a suspected interference is to test the specimen by a different manufacturer's method and check for discordance between the test results. Occasionally, a biological check can be made using TRH-stimulation or thyroid hormone suppression to validate a suspected inappropriate serum TSH level. Interferences producing a falsely elevated TSH value will usually be associated with a blunted $(<2$-fold increase) response to stimulation.

Some examples of potential TSH assay interference include: (1) issues with cross reactivity, (2) endogenous antibodies to TSH, (3) heterophile (animal) antibody interference with assay reagents and (4) in vivo or in vitro drug interactions. It should be noted that there are clinical situations in which the measurements of serum TSH alone may yield misleading results (Table 1).

(1) Cross-reactivity. The specificity of an immunoassay depends on the ability of the antibody reagent to discriminate flawlessly between the analyte and structurally related ligands. The use of monoclonal antibodies for developing TSH immunoassay methods has virtually eliminated the cross-reactivity problems with other glycoprotein hormones, such as LH or hCG, that had plagued early TSH radioimmunoassay methods. However, because each monoclonal

\begin{tabular}{|c|c|c|c|}
\hline Condition & Serum TSH & $\begin{array}{l}\text { Consequences of Clinical } \\
\text { Action based on Serum TSH } \\
\text { value Alone }\end{array}$ & Serum FT4 \\
\hline Heterophile antibodies & Normal & $\begin{array}{l}\text { Failure to diagnose } \\
\text { thyrotoxicosis }\end{array}$ & High \\
\hline Central hypothyroidism & Normal* $^{*}$ & $\begin{array}{l}\text { Failure to diagnose } \\
\text { hypothyroidism and } \\
\text { investigate hypothalamic- } \\
\text { pituitary structure function }\end{array}$ & Low \\
\hline $\begin{array}{l}\text { TSH-secreting pituitary } \\
\text { adenoma }\end{array}$ & Normal $^{*}$ & $\begin{array}{l}\text { Failure to diagnose } \\
\text { thyrotoxicosis and } \\
\text { investigate pituitary structure } \\
\text { and function }\end{array}$ & High \\
\hline $\begin{array}{l}\text { Thyroid hormone } \\
\text { resistance }\end{array}$ & Normal* $^{*}$ & $\begin{array}{l}\text { Failure to recognize the } \\
\text { condition }\end{array}$ & High \\
\hline $\begin{array}{l}\text { Poor compliance with } \\
\text { T4 therapy }\end{array}$ & High & $\begin{array}{l}\text { Inappropriate increase in } \\
\text { dose of } \mathrm{T} 4\end{array}$ & High \\
\hline $\begin{array}{l}\text { Delayed recovery } \\
\text { of TSH secretion } \\
\text { after treatment of } \\
\text { hyperthyroidism }\end{array}$ & Normal or low & $\begin{array}{l}\text { Failure to diagnose } \\
\text { impending hypothyroidism }\end{array}$ & Low \\
\hline
\end{tabular}

*Serum TSH concentrations may also be high in these conditions, which should prompt measurements of serum $\mathrm{FT}_{4}$ and further investigation

Table 1: Clinical situations in which measurements of serum TSH alone may yield misleading results. antibody differs in its specificity for recognizing various circulating TSH isoforms, these antibody differences can result in the reporting of TSH values that may differ by as much as $1.0 \mathrm{mIU} / \mathrm{L}$ for a given serum sample [23].

(2) Endogenous Antibodies. Endogenous antibody interferences are characterized by either falsely low or falsely high values, depending on the type and composition of the antibody assay employed.

(3) Heterophile Antibodies (HAb)/Human Anti-Mouse Antibodies (HAMA). Heterophile antibodies represent a group of relatively weak multispecific, polyreactive antibodies with specificity for poorly defined antigens that react with immunoassays derived from two or more species [24,25]. Most frequently, such HAb interferences result from IgM Rheumatoid Factor or HAMA. Immunometric assay methods that use monoclonal antibodies of murine origin are more prone to HAMA interference than competitive immunoassays and create a signal that is reported as a falsely high value [26]. Such HAMA interference can produce inappropriately normal values in patients that eventually prove to have clinical disease [27]. Despite the measures used by manufacturers to neutralize interferences, both the clinician and the laboratory must be aware of this possibility when an apparently inappropriate test result is encountered.

(4) Drug Interferences. Certain drugs may interfere with TSH levels in-vitro or in-vivo $[28,29]$. Drugs can have in-vitro or in vivo effects if serum samples contain sufficient concentrations of certain therapeutic and diagnostic agents to produce methodological interference. For example, glucocorticoids can have in-vivo effects on thyroid function by altering TSH, thyroid hormone secretion, and/or thyroid hormone metabolism [28,29].

A number of drugs cause hypothyroxinemia in euthyroid patients by decreasing TBG concentrations (androgens, niacin), decreasing T4 binding to TBG (high dose salicylates, phenytoin, carbamazepine), and/or increasing $\mathrm{T}_{4}$ metabolism (carbamazepine, phenobarbital and phenytoin). Some drugs cause hyperthyroxinemia in euthyroid patients by increasing TBG concentrations (clofibrate, estrogen, 5FU, heroin/ methadone) [28-30], while other drugs may raise circulating $\mathrm{T}_{4}$ levels by inhibiting the conversion of $\mathrm{T}_{4}$ to $\mathrm{T}_{3}$ (amiodarone, iopanoic acid and high-dose propranolol and nadolol).

\section{TSH with Impaired Biological Activity}

A high level of serum TSH may be the result of a laboratory issue, although rare, namely the presence of biologically inactive isoforms of TSH. This would result from pituitary-hypothalamic disease in an individual whose basal TSH levels measured by immunoassay were elevated, yet when measured by a cytochemical bioassay were found to be normal [31]. This finding, coupled with the absence of the normal rise of thyroid hormones in response to thyrotrophinreleasing hormone (TRH)-mediated release of TSH, confirm the secretion of bio-inactive TSH. Primary thyroid disease as a cause for the elevated immunoreactive TSH can be excluded by the absence of circulating thyroid antibodies and by a normal thyroidal radioiodine uptake response to exogenous TSH. In patients with idiopathic central hypothyroidism due to biologically inactive TSH, there is an excess of circulating TSH-beta and TRH is implicated in the secretion of TSH of full biological potency [32]. Such sera will indicate elevated TSH concentrations (immunoacivity) although the bioactivity may be normal.

High TSH levels are often observed in long-lasting and severe hypothyroidism. Yet, a case report of a 25 year old man with Down's 
Syndrome showed that having high TSH levels does not necessarily result in the clinical manifestation of hypothyroidism. In this study, the patient had TSH levels of $1392 \mathrm{mIU} / \mathrm{L}$ (normal reference interval 0.25 $4.0 \mathrm{mIU} / \mathrm{L})$ and FT4 of $0.66 \mathrm{pmol} / \mathrm{L}(8.2-18 \mathrm{pmol} / \mathrm{L})$. This discrepancy between the clinical symptoms and immunoassay results is not uncommon, and may be explained by impaired biological activity of specific TSH isoforms [12].

\section{Defining TSH Reference Intervals}

Setting reference intervals for TSH is critical for diagnosing mild (subclinical) hypo- or hyperthyroidism. The current clinical guidelines recommend that TSH reference intervals should be established from the $95 \%$ confidence limits of the log-transformed TSH concentrations of at least 120 rigorously screened normal euthyroid volunteers who have: (a) no detectable anti-thyroid peroxidase autoantibodies (TPOAb) or anti-thyroglobulin autoantibodies (TgAb) measured by sensitive immunoassay; (b) no personal or family history of thyroid dysfunction; (c) no visible or palpable goiter; and (d) who are taking no medications except estrogen [4]

\section{TSH upper reference limits $\left(97.5^{\text {th }}\right.$ percentile $)$}

Multiple factors influence the calculation of the TSH upper reference limit for a population. These include factors such as sex, age, ethnicity, iodine intake, body mass index (BMI), smoking, subclinical autoimmune thyroid disease, education level, medications, socioeconomic status [33] and may affect thyroid function resulting in elevated TSH listed in table 2. Over the last two decades, the upper reference limit for TSH has steadily declined from approximately 10 $\mathrm{mIU} / \mathrm{L}$ to $2.5-3.5 \mathrm{mIU} / \mathrm{L}$. This decrease reflects a number of factors including the improved sensitivity and specificity of current monoclonal antibody-based immunometric TSH assays, the elimination of high values resulting from gonadotropin cross-reactivity, and the exclusion of individuals with subclinical autoimmune thyroid disease who have higher TSH values [4,34]

Some guidelines propose the adoption of an empirical upper limit of 2.5-3.0 mIU/L, which is in accordance with the TSH interval associated with the lowest prevalence of anti-thyroid antibodies [4,35]. However, this remains controversial, since the majority of persons with serum TSH levels between 2.5 and $4.0 \mathrm{mIU} / \mathrm{L}$ have no evidence of thyroid disease serologically or on ultrasonography $[9,36,37]$. In 2002, the American Association of Clinical Endocrinologists suggested that the serum TSH reference range upper limit be lowered to $3.0 \mathrm{mIU} / \mathrm{L}$ [5], while others support an additional decrease to $2.5 \mathrm{mIU} / \mathrm{L}$ [38], based

\begin{tabular}{|c|c|}
\hline Assay-related & $\begin{array}{l}\text { Bioinactive TSH secretion } \\
\text { Heterophile antibodies }\end{array}$ \\
\hline Dysfunctions of the thyroid gland & $\begin{array}{l}\text { Family history of thyroid disease (latent } \\
\text { thyroid disorder) } \\
\text { TSH resistance syndromes } \\
\text { Thyroid hormone resistance } \\
\text { Germline mutations of TSH receptor } \\
\text { Hashimoto thyroiditis } \\
\text { Other autoimmune conditions } \\
\text { Recovery phase of subacute thyroiditis }\end{array}$ \\
\hline Dysfunctions of the pituitary gland & Pituitary tumors (TSH-producing) \\
\hline Environmental & $\begin{array}{l}\text { Pregnancy } \\
\text { lodine deficiency } \\
\text { Radioactive iodine treatment } \\
\text { Medications (steroids, dopamine, iodine, } \\
\text { amiodarone) } \\
\text { Nonthyroidal illness } \\
\text { Insufficient medication in individuals with a } \\
\text { thyroid disorder }\end{array}$ \\
\hline
\end{tabular}

Table 2: Causes of Elevated Serum TSH Concentrations. on a recent report by the National Academy of Clinical Biochemistry that over $95 \%$ of normal, healthy individuals have serum TSH between 0.4 and $2.5 \mathrm{mIU} / \mathrm{liter}$, and that those with TSH $>2.5 \mathrm{mIU} /$ liter may be in the early stages of thyroid failure, particularly when TPOAb are present [39]. Similar findings suggest the use of TSH cutoff values of 2.5 and 4.0 $\mathrm{mIU} / \mathrm{L}$ in addition to thyroid antibodies as clinically useful estimates of long-term risk of hypothyroidism [40].

Although Surks acknowledges equivalently that serum TSH levels between 3.0 and 4.5 may indicate the earliest signs of subclinical hypothyroidism, the concern is that an upper limit of 2.5-3.0 mIU/ liter would create a $300-400 \%$ increase in individuals diagnosed as hypothyroid (22-28 million additional individuals) when in reality they are not clinically in need of any treatment [41]. Fatourechi [42] comments on this phenomenon, noting that, as TSH distribution and peak frequency (most commonly occurring serum TSH level) shift toward higher levels with increased age in both a disease-free population and thyroid antibody-negative reference population for subjects who are without any evidence of thyroid disease, the lowering of the upper limit of the TSH reference range could result in a tripling of abnormal results in individuals over 50 years of age, again, causing unrealistic concern for clinical intervention.

\section{TSH lower reference limits}

Using current third generation IMA methodology, the lower TSH reference limit $\left(2.5^{\text {th }}\right.$ percentile) is approximately 0.3 to $0.4 \mathrm{mIU} / \mathrm{L}$, irrespective of the population studied or the method used [43]. TSH in the 0.1 to $0.4 \mathrm{mIU} / \mathrm{L}$ range may represent mild thyroid hormone excess, and in elderly patients might be associated with an increased risk of atrial fibrillation and cardiovascular mortality [44]. It is also important to note a shift in TSH distribution in blacks [36], leading to possible over-diagnosis of subclinical hyperthyroidism. It is therefore important to carefully evaluate patients with TSH levels in this low range for underlying thyroid disease.

\section{Hospitalized patients}

Non-thyroidal illnesses (NTI) can frequently alter thyroid hormone peripheral metabolism and Hypothalamic-Pituitary-Thyroidal (HPT) function resulting in thyroid test abnormalities, including both decreased and increased serum TSH levels [45]. It is important to distinguish the generally mild, transient TSH alterations typical of NTI from the more profound and persistent TSH changes associated with hyper- or hypothyroidism [46].

One would be remiss to exclude mention of the fact that populationbased reference intervals include not only between-individual variation, but within-individual as well. Research studies report that within-person (intra-individual) TSH variability is relatively narrow, and varies by only $0.5 \mathrm{mIU} / \mathrm{L}$ when tested every month over a span of one year. In comparison, between-person variability is more variable [47-49]. Consequently, it is highly possible that abnormal test results for a single individual may go largely undetected if still within the normal range for the wider population-in fact, when the index of individuality for a thyroid test is below $0.6 \mathrm{mIU} / \mathrm{L}$, population-based reference intervals are fairly unreliable at gauging individual change [50]. This somewhat limits the usefulness of population-based reference intervals to detect thyroid dysfunction in individuals [7,51]. Theoretically, it may be important to evaluate individuals with marginally (yet confirmed) low (e.g, 0.3-0.4 mIU/L) or high (3.0-4.5 mIU/L) TSH levels relative to patient-specific risk factors for cardiovascular disease, rather than relative to the normal TSH reference interval [52]. However, there are 
no data to show increased morbidity and mortality if an individual's TSH levels are not within their own normal range, as long as they are within the population reference interval.

\section{Diurnal variation}

Serum TSH normally exhibits a diurnal variation with a peak between midnight and 04:00 and the lowest values between 10:00 and 16:00 hours [20]. This variation should not influence the diagnostic interpretation of test results since most clinical TSH measurements are performed on ambulatory patients between 08:00 and 18:00 hours, and the reference intervals for TSH are typically established using specimens collected at a similar time. Further, because serum T4 with a half-life of approximately 7 days does not change sufficiently in one day to raise TSH secretion, there is no need to withhold LT4 therapy on the day of blood testing for TSH [4].

\section{Population-Based Reference Intervals}

Population-based studies rely on non-homogenous populations with varying genetic, dietary intake, environmental exposures and behaviors. As noted, a positive relationship is detected between elevated serum TSH levels and the presence of TPOAb antibodies $[53,54]$ and is directly related to the diagnosis of subclinical (mild) hypothyroidism when serum T4 levels are within normal. The third National Health and Nutrition Examination Survey (NHANES III) (1988-1994), is a crosssectional study representative of the US population and includes 17,353 individuals aged $\geq 12 \mathrm{yr}$ [55]. Analysis of NHANES III concluded that the geometric mean serum TSH concentration for the US population was 1.47 (95\% confidence interval 1.44-1.51) mIU/liter, and a median TSH concentration of 1.39 (1.35-1.47) $\mathrm{mIU} / \mathrm{liter}$. The $2.5 \% \mathrm{TSH}$ lower reference limit was $0.45(0.42-0.47) \mathrm{mIU} /$ liter and the $97.5 \% 4.12$ (3.944.45) $\mathrm{mIU} /$ liter [55].

\section{Serum TSH Levels In The Elderly And In Centenarians}

Several epidemiological studies indicate that the population's mean TSH levels increase with age $[55,56]$. In the NHANES III survey of the U.S. population, the $97.5^{\text {th }}$ percentile for serum TSH has been shown to be higher in groups of elderly, or white individuals, women, and those with higher iodine intake than in other population subgroups, suggesting specific TSH reference limits, which are not currently available, should be considered for specific populations $[10,36,57,58]$.

Epidemiological studies illustrate that TSH distribution and reference limits shift to higher concentrations with age, even up to centenarians, and are unique for different racial/ethnic groups, being at higher concentrations in Caucasians than either Blacks or Hispanics. The distribution curve for TSH derived by the traditional approach represents a composite of curves from specific subpopulations that do not provide appropriate reference limits for those unique groups [36]. However, other more controlled studies claim that serum TSH concentrations decrease in healthy elderly subjects due to an agerelated decrease in TSH secretion by the pituitary [59]. Several studies have reported an association between low serum TSH and cognitive impairement in the elderly, predicting the risk of mild cognitive disease. However, despite new data and meta-analysis the association between serum TSH concentrations and cognition in the elderly remains a controversial issue [60-64].

In the elderly, the nocturnal TSH peak is blunted and there is a 1-1.5 hour shift in the circadian rhythm of TSH secretion, resulting in an earlier TSH peak $[65,66]$. The mechanism of this reduction in TSH secretion is currently unknown. It may very well be an increased sensitivity of the thyrotrophs to the negative feedback by T4, but other mechanisms such as a reduced hypothalamic thyrotropin releasing hormone (TRH) secretion cannot be excluded [4]. Although reduced TSH levels result in a reduced thyroidal T4 secretion in the elderly $[67,68]$, serum TT4 and FT4 concentrations remain unchanged $[4,69]$. This is because T4 degradation by outer ring deiodination decreases with age resulting in age-dependent decline in TT3 and FT3 levels and an increase in the biologically inactive serum reverse T3 (rT3) levels. It is currently unknown whether an increased inner ring deiodination by deiodinase 3, which would result in an increased clearance of T4 and T3 and an increased production of rT3, also contributes to these changes. This has recently been shown to be a major factor in non-thyroidal illness [70,71]. A multitude of other studies negates that elevated TSH is indicative of increased prevalence of hypothyroidism, proposing that there is simply an age-related increase in serum TSH concentrations based on an alteration in TSH set point rather than thyroid disease [7]. Additionally, the definition of what should, in fact, be considered a "normal" reference interval for TSH concentration is still under debate.

The reliability of TSH reference intervals based on population data that includes individuals who are positive for anti-thyroid antibodies has been questioned due to the association between elevated TSH concentrations and the presence of anti-thyroid antibodies, which could be associated with occult thyroid disease. Such population-based studies reported that the likelihood of having TPOAb increased with a TSH level greater than $2 \mathrm{mIU} / \mathrm{L}$, approaching $80 \%$ prevalence when TSH concentrations were greater than $20 \mathrm{mIU} / \mathrm{L}$ and both TPOAb and $\mathrm{TgAb}$ were present. However, no thyroid antibodies were detected in $31 \%$ of males and $11 \%$ of females with TSH $>10$ mIU/L. Namely, even when there are no thyroid antibodies detected, the upper reference range limit is still skewed [35].

Surks et al. [9] argues that the TSH distribution curve is in fact a composite of separate curves for unique subpopulations (i.e. ages, ethnicities, genders) that contributes to an apparent skew toward higher TSH values $[9,36]$. The authors propose that increasing mean TSH levels above $4.5 \mathrm{mIU} / \mathrm{L}$ with advanced age are not associated with thyroid disease, but rather due to distinct TSH reference ranges for separate age groups that shift toward higher values with increasing age. It is suggested that age-specific reference intervals should be used to avoid misclassification of patients with abnormal TSH as hypothyroid [9].

These findings are consistent with those of a study that analyzed NHANES III data to recommend a more practical approach for establishing age-specific TSH reference ranges that do not include individuals who are positive for circulating anti-thyroid antibodies, whose presence is associated with thyroid dysfunction [10]. This study found that the $2.5^{\text {th }}, 50^{\text {th }}$, and $97.5^{\text {th }}$ percentiles of TSH increase with age, with the most significant effects seen at the $97.5^{\text {th }}$ percentile, which increases by $0.3 \mathrm{mIU} / \mathrm{L}$ with each 10 year increase in a subject's age [10].

The second, and more controversial, debate over TSH reference ranges is in defining their limits. There is limited information on the lower limit apart from an association between risk of atrial fibrillation and low TSH concentrations (three times greater risk in TSH $<0.1$ $\mathrm{mIU} / \mathrm{L}, 1.6$ times the risk in $0.1 \mathrm{mIU} / \mathrm{L}<\mathrm{TSH}<0.4 \mathrm{mIU} / \mathrm{L})[5,72,73]$. Others maintain that in the absence of clinical-intervention trials on hyperthyroidism, the medical community should adopt a risk-based approach for establishing thresholds to justify interventions rather than determining reference intervals [73].

The debate over TSH reference ranges is complex and ongoing, 
and relies heavily on interpretations of data that report elevated TSH concentrations in relation to either thyroid dysfunction or merely as another aspect of healthy aging. Several studies, in fact, draw correlations between elevated serum TSH (and thus decreased thyroid function) and increased longevity in the elderly [74-76], an association to be discussed later in this article. Nevertheless, it is essential that a certain consensus is reached regarding the most appropriate TSH reference range, for misclassification of healthy patients as hypothyroid could result in unnecessary levothyroxine treatment and its related consequences, while incorrectly characterizing a thyroid disorder as normal may enhance the risk of progression from mild to overt hypothyroidism [52].

Isolated abnormalities of serum TSH levels do not necessarily connote sustained thyroid dysfunction. Some causes of isolated TSH elevation may include: (1) mild (subclinical) hypothyroidism, (2) recovery from hypothyroxinemia of nonthyroid illnesses, and (3) medications such as amiodarone, which can inhibit thyroid hormone synthesis and metabolism and may cause transient reversible elevation of serum TSH [77]. Hyperthyroid patients are expected to have serum TSH concentrations of less than $0.01 \mathrm{mIU} / \mathrm{L}$ except in TSH-induced thyrotoxicosis and T4/T3 resistance. Patients with resistance to thyroid hormones may have mixed thyroid status, with hypothyroidism in some tissues and thyrotoxicosis in others, resulting in normal or mildly elevated TSH levels. Isolated TSH suppression can be observed in cases of mild (subclinical) hyperthyroidism, recovery from overt hyperthyroidism, nonthyroidal illnesses, or in patients using medications such as dopamine and high-dose glucocorticoids.

\section{Is Higher TSH Related to Genetic Predisposition to Longevity?}

A comparison study based on 1981 and 1994 cross-sectional Busselton Health Surveys concluded that there is a significant positive correlation between age and serum TSH concentrations ( $\mathrm{r}=0.092$, $p<0.001$ ) [78]. Based on reference populations free of thyroid disease, the study demonstrated that there was an increase of $0.08 \mathrm{mIU} / \mathrm{L}$ serum TSH per decade of age at baseline, with the largest increases occurring in the oldest participants and those with the lowest TSH at baseline [78]. A different study of a thyroid disease-free Ashkenazi Jewish population determined that mean serum TSH was significantly higher in centenarians with median age 98 yr [1.97 (0.42-7.15) mIU/L] than in Ashkenazi controls of a younger age [1.55 (0.46-4.55) mIU/L], and NHANES III controls median age 68 yr [1.61 (0.39-6.29) mIU/L] [76]. Based on the inverse relationship between TSH and FT4, the age-related changes in the negative feedback mechanism, namely the slowing down in reactive response between TSH and thyroid hormones may be a factor contributing to longevity. The age-related increase in TSH concentrations for subjects older than 90 years of age were only slightly more elevated than those of younger adults [79].

Despite major studies and surveys such as NHANES III, several publications challenge the notion of elevated TSH in centenarians. In a small cross-sectional study conducted in Italy serum TSH concentrations were lower in centenarians (mean age $101.96 \pm 0.38$ SEM) than in healthy older subjects (mean age $84.75 \pm 1.25$ SEM), while reverse-T3 concentrations were higher, suggesting an age-dependent reduction of the 5 -deiodinase activity rather than to important changes of nutritional markers [80]. The study, however, was based on a small sample size and Italy is known to be mildly iodine deficient and thus results must be interpreted cautiously.

A genetic association between longevity and higher TSH is another possibility. It has been observed, among those centenarians with elevated TSH, their offspring have raised serum TSH concentrations in comparison with age-matched controls, suggesting an effect on TSHR gene expression inherited from centenarians and contributing to increased TSH [81]. The 2010 Leiden Longevity Study similarly finds an association between lower family mortality history scores among parents of nonagenarian siblings and higher serum TSH levels, suggesting that decreased thyroid function (represented by the elevated serum TSH) is a heritable phenotype contributing to exceptional longevity [82].

Further research would suggest that extreme longevity correlates not only with TSH values, but also with thyroid function itself. Based on the possible relationship between elevated TSH and decreased thyroid function, Atzmon et al. hypothesize that there is an inverse correlation between thyroid function and life span [81], while animal studies suggest that the relationship may be causal $[83,84]$. An analysis of the subjective well-being of hypothyroid patients seems to corroborate these findings, concluding that elevated serum TSH concentrations in the elderly subjects are significantly less indicative of hypothyroid disease and its repercussions than in younger subjects $[85,86]$. Thyroidal production of thyroid hormones may decrease in advanced age, perhaps reflecting centenarians' adaptations to new physical requirements rather than true deficits in thyroid system functioning [87-89].

\section{Conclusion}

Changes in serum TSH concentrations are often described in elderly subjects; however, their pathophysiologic significance and the possible contributory role of both malnutrition and nonthyroidal illness are still debated. Despite the occasional challenge of any relation between TSH level and age, the general assumption is that either hypothyroidism is increasingly prevalent among older members of the population, or there is merely an age-related rise in TSH set point beyond any evidence of thyroid disease. And yet, age is only one of many variables with a moderately strong influence on TSH level. Factors such as laboratory assessment, sex, ethnicity, diet, education level, medications, socioeconomic status, body mass index and smoking [33] may play affect in thyroid function resulting in elevated TSH. It is, therefore, essential to be mindful of the interplay of variables on thyroid function, and proceed accordingly in terms of treatment and diagnosis.

The controversy arising from the distinction of elevated TSH levels in the elderly as a normal consequence of aging or potentially as a sign of increased prevalence of hypothyroidism in the elderly is vast. It includes efforts to define more adequate serum TSH reference intervals for older adults, research into the potential contribution of decreased thyroid function to increased longevity, and the ever-present question of whether or not to treat for a dysfunction that may or may not be present.

\section{Acknowledgement}

Dr. Soldin is supported in part by NIH R01AG033867-01 and by FAMRI, the Flight Attendants Medical Research Institute. The authors would like to thank Sarah Chung and Josh Estrada for their helpful comments.

\section{References}

1. Garber JR, Cobin RH, Gharib H, Hennessey JV, Klein I, et al. (2012) Clinica Practice Guidelines for Hypothyroidism in Adults: Co-sponsored by American Association of Clinical Endocrinologists and the American Thyroid Association. Endocr Pract 11: 1-207.

2. Stagnaro-Green A, Abalovich M, Alexander E, Azizi F, Mestman J, et al. (2011) Guidelines of the American Thyroid Association for the diagnosis and 
Citation: Deary M, Buckey T, Soldin OP (2012) TSH - Clinical Aspects of its Use in Determining Thyroid Disease in the Elderly How does it Impact the Practice of Medicine in Aging? Adv Pharmacoepidem Drug Safety 1:119. doi:10.4172/2167-1052.1000119

management of thyroid disease during pregnancy and postpartum. Thyroid 21 : 1081-1125.

3. Grossmann M, Weintraub BD, Szkudlinski MW (1997) Novel insights into the molecular mechanisms of human thyrotropin action: structural, physiological, and therapeutic implications for the glycoprotein hormone family. Endocr Rev 18: $476-501$

4. Baloch Z, Carayon P, Conte-Devolx B, Demers LM, Feldt-Rasmussen U, et al. (2003) Laboratory medicine practice guidelines. Laboratory support for the diagnosis and monitoring of thyroid disease. Thyroid 13: 3-126.

5. Baskin HJ, Cobin RH, Duick DS, Gharib H, Guttler RB, et al. (2002) American Association of Clinical Endocrinologists medical guidelines for clinical practice for the evaluation and treatment of hyperthyroidism and hypothyroidism. Endocr Pract 8: 457-69.

6. Haugen BR (2009) Drugs that suppress TSH or cause central hypothyroidism Best Pract Res Clin Endocrinol Metab 23: 793-800.

7. Benhadi N, Fliers E, Visser TJ, Reitsma JB, Wiersinga WM (2010) Pilot study on the assessment of the setpoint of the hypothalamus-pituitary-thyroid axis in healthy volunteers. Eur J Endocrinol 162: 323-329.

8. Meikle AW, Stringham JD, Woodward MG, Nelson JC (1988) Hereditary and environmental influences on the variation of thyroid hormones in normal male twins. J Clin Endocrinol Metab 66: 588-592.

9. Surks MI, Hollowell JG (2007) Age-specific distribution of serum thyrotropin and antithyroid antibodies in the US population: implications for the prevalence of subclinical hypothyroidism. J Clin Endocrinol Metab 92: 4575-4582.

10. Boucai L, Hollowell JG, Surks MI (2011) An approach for development of agegender-, and ethnicity-specific thyrotropin reference limits. Thyroid 21: 5-11.

11. Sawin CT, Herman T, Molitch ME, London MH, Kramer SM (1983) Aging and the thyroid. Decreased requirement for thyroid hormone in older hypothyroid patients. Am J Med 75: 206-209.

12. Gauchez AS, Pizzo M, Alcaraz-Galvain D, Chikh K, Orgiazzi J, et al. (2010) TSH Isoforms: About a Case of Hypothyroidism in a Down's Syndrome Young Adult. J Thyroid Res 2010: 703978.

13. Beckett GJ, Toft AD (2003) First-line thyroid function tests -- TSH alone is not enough. Clin Endocrinol (Oxf) 58: 20-21.

14. Rawlins ML, Roberts WL (2004) Performance characteristics of six thirdgeneration assays for thyroid-stimulating hormone. Clin Chem 50: 2338-2344.

15. Ladenson PW, Singer PA, Ain KB, Bagchi N, Bigos ST, et al. (2000) American Thyroid Association guidelines for detection of thyroid dysfunction. Arch Intern Med 160: 1573-1575.

16. Canaris GJ, Manowitz NR, Mayor G, Ridgway EC (2000) The Colorado thyroid disease prevalence study. Arch Intern Med 160: 526-534.

17. Sawin CT (1995) Subclinical hypothyroidism in older persons. Clin Geriatr Med 11: $231-238$.

18. American Thyroid Association (ATA) Guidelines Taskforce on Thyroid Nodules and Differentiated Thyroid Cancer, Cooper DS, Doherty GM, Haugen BR, Kloos RT, et al. (2009) Revised American Thyroid Association management guidelines for patients with thyroid nodules and differentiated thyroid cancer Thyroid 19: 1167-1214.

19. Jonklaas J, Sarlis NJ, Litofsky D, Ain KB, Bigos ST, et al. (2006) Outcomes of patients with differentiated thyroid carcinoma following initial therapy. Thyroid 16: $1229-1242$

20. Brabant G, Prank K, Hoang-Vu C, Hesch RD, von zur Mühlen A (1991) Hypothalamic regulation of pulsatile thyrotopin secretion. J Clin Endocrinol Metab 72: $145-150$

21. Carr D, McLeod DT, Parry G, Thornes HM (1988) Fine adjustment of thyroxine replacement dosage: comparison of the thyrotrophin releasing hormone test using a sensitive thyrotrophin assay with measurement of free thyroid hormones and clinical assessment. Clin Endocrinol (Oxf) 28: 325-333.

22. Thienpont LM, Van Uytfanghe K, Beastall G, Faix JD, leiri T, et al. (2010) Report of the IFCC Working Group for Standardization of Thyroid Function Tests, Part 2: Free Thyroxine and Free Triiodothyronine. Clin Chem 56: 912-920.

23. Silvio R, Swapp KJ, La'ulu SL, Hansen-Suchy K, Roberts WL (2009) Method specific second-trimester reference intervals for thyroid-stimulating hormone and free thyroxine. Clin Biochem 42: 750-753.
24. Van Houcke SK, Van Uytfanghe K, Shimizu E, Tani W, Umemoto M, et al. (2011) IFCC international conventional reference procedure for the measurement of free thyroxine in serum: International Federation of Clinical Chemistry and Laboratory Medicine (IFCC) Working Group for Standardization of Thyroid Function Tests (WG-STFT)(1). Clin Chem Lab Med 49: 1275-1281.

25. Thienpont LM (2008) A major step forward in the routine measurement of serum free thyroid hormones. Clin Chem 54: 625-626.

26. International Federation of Clinical Chemistry and Laboratory Medicine IFCC, IFCC Scientific Division Working Group for Standardization of Thyroid Function Tests WG-STFT, Thienpont LM, Beastall G, Christofides ND, et al. (2007) Proposal of a candidate international conventional reference measurement procedure for free thyroxine in serum. Clin Chem Lab Med 45: 934-936.

27. Van Uytfanghe K, StöckI D, Ross HA, Thienpont LM (2006) Use of frozen sera for FT4 standardization: investigation by equilibrium dialysis combined with isotope dilution-mass spectrometry and immunoassay. Clin Chem 52: 1817 1821.

28. Steele BW, Wang E, Klee GG, Thienpont LM, Soldin SJ, et al. (2005) Analytic bias of thyroid function tests: analysis of a College of American Pathologists fresh frozen serum pool by 3900 clinical laboratories. Arch Pathol Lab Med 129: 310-317.

29. Stockigt JR, Lim CF (2009) Medications that distort in vitro tests of thyroid function, with particular reference to estimates of serum free thyroxine. Best Pract Res Clin Endocrinol Metab 23: 753-767.

30. Stockigt JR (2001) Free thyroid hormone measurement. A critical appraisal. Endocrinol Metab Clin North Am 30: 265-289.

31. Belchetz PE (1976) Idiopathic hypopituitarism with biologically inactive TSH Proc R Soc Med 69: 428-429.

32. Faglia G, Beck-Peccoz P, Ballabio M, Nava C (1983) Excess of beta-subunit of thyrotropin (TSH) in patients with idiopathic central hypothyroidism due to the secretion of TSH with reduced biological activity. J Clin Endocrinol Metab 56: $908-914$

33. Suzuki S, Nishio S, Takeda T, Komatsu M (2012) Gender-specific regulation of response to thyroid hormone in aging. Thyroid Res 5: 1.

34. Jensen E, Hyltoft Petersen P, Blaabjerg O, Hansen PS, Brix TH, et al. (2004) Establishment of a serum thyroid stimulating hormone (TSH) reference interval in healthy adults. The importance of environmental factors, including thyroid antibodies. Clin Chem Lab Med 42: 824-832.

35. Spencer CA, Hollowell JG, Kazarosyan M, Braverman LE (2007) Nationa Health and Nutrition Examination Survey III thyroid-stimulating hormone (TSH)thyroperoxidase antibody relationships demonstrate that TSH upper reference limits may be skewed by occult thyroid dysfunction. J Clin Endocrinol Metab 92: 4236-4240.

36. Surks MI, Boucai L (2010) Age- and race-based serum thyrotropin reference limits. J Clin Endocrinol Metab 95: 496-502.

37. Hamilton TE, Davis S, Onstad L, Kopecky KJ (2008) Thyrotropin levels in a population with no clinical, autoantibody, or ultrasonographic evidence of thyroid disease: implications for the diagnosis of subclinical hypothyroidism. J Clin Endocrinol Metab 93: 1224-1230.

38. Wartofsky L, Dickey RA (2005) The evidence for a narrower thyrotropin reference range is compelling. J Clin Endocrinol Metab 90: 5483-5488.

39. Demers LM, Spencer CA (2003) Laboratory medicine practice guidelines: laboratory support for the diagnosis and monitoring of thyroid disease. Clin Endocrinol (Oxf) 58: 138-140

40. Walsh JP, Bremner AP, Feddema P, Leedman PJ, Brown SJ, et al. (2010) Thyrotropin and thyroid antibodies as predictors of hypothyroidism: a 13-year, longitudinal study of a community-based cohort using current immunoassay techniques. J Clin Endocrinol Metab 95: 1095-1104.

41. Surks MI, Goswami G, Daniels GH (2005) The thyrotropin reference range should remain unchanged. J Clin Endocrinol Metab 90: 5489-5496.

42. Fatourechi V, Klee GG, Grebe SK, Bahn RS, Brennan MD, et al. (2003) Effects of reducing the upper limit of normal TSH values. JAMA 290: 3195-3196.

43. d'Herbomez M, Jarrige V, Darte C (2005) Reference intervals for serum thyrotropin (TSH) and free thyroxine (FT4) in adults using the Access Immunoassay System. Clin Chem Lab Med 43: 102-105.

44. Heeringa J, Hoogendoorn EH, van der Deure WM, Hofman A, Peeters RP, et al 
Citation: Deary M, Buckey T, Soldin OP (2012) TSH - Clinical Aspects of its Use in Determining Thyroid Disease in the Elderly How does it Impact the Practice of Medicine in Aging? Adv Pharmacoepidem Drug Safety 1:119. doi:10.4172/2167-1052.1000119

(2008) High-normal thyroid function and risk of atrial fibrillation: the Rotterdam study. Arch Intern Med 168: 2219-2224.

45. Mebis L, van den Berghe G (2009) The hypothalamus-pituitary-thyroid axis in critical illness. Neth J Med 67: 332-340.

46. Stockigt JR (1996) Guidelines for diagnosis and monitoring of thyroid disease: nonthyroidal illness. Clin Chem 42: 188-192.

47. Andersen S, Pedersen KM, Bruun NH, Laurberg P (2002) Narrow individual variations in serum $\mathrm{T}(4)$ and $\mathrm{T}(3)$ in normal subjects: a clue to the understanding of subclinical thyroid disease. J Clin Endocrinol Metab 87: 1068-1072.

48. Andersen S, Bruun NH, Pedersen KM, Laurberg P (2003) Biologic variation is important for interpretation of thyroid function tests. Thyroid 13: 1069-1078.

49. Ankrah-Tetteh T, Wijeratne S, Swaminathan R (2008) Intraindividual variation in serum thyroid hormones, parathyroid hormone and insulin-like growth factor-1. Ann Clin Biochem 45: 167-169.

50. Harris EK (1974) Effects of intra- and interindividual variation on the appropriate use of normal ranges. Clin Chem 20: 1535-1542.

51. Boas M, Forman JL, Juul A, Feldt-Rasmussen U, Skakkebaek NE, et al. (2009) Narrow intra-individual variation of maternal thyroid function in pregnancy based on a longitudinal study on 132 women. Eur J Endocrinol 161: 903-910.

52. Biondi B, Cooper DS (2008) The clinical significance of subclinical thyroid dysfunction. Endocr Rev 29: 76-131.

53. Vanderpump MP, Tunbridge WM, French JM, Appleton D, Bates D, et al. (1995) The incidence of thyroid disorders in the community: a twenty-year follow-up of the Whickham Survey. Clin Endocrinol (Oxf) 43: 55-68.

54. Bjoro T, Holmen J, Krüger O, Midthjell K, Hunstad K, et al. (2000) Prevalence of thyroid disease, thyroid dysfunction and thyroid peroxidase antibodies in a large, unselected population. The Health Study of Nord-Trondelag (HUNT). Eur J Endocrinol 143: 639-647.

55. Hollowell JG, Staehling NW, Flanders WD, Hannon WH, Gunter EW, et al. (2002) Serum TSH, T(4), and thyroid antibodies in the United States population (1988 to 1994): National Health and Nutrition Examination Survey (NHANES III). J Clin Endocrinol Metab 87: 489-499.

56. Brochmann H, Bjøro T, Gaarder PI, Hanson F, Frey HM (1988) Prevalence of thyroid dysfunction in elderly subjects. A randomized study in a Norwegian rura community (Naerøy). Acta Endocrinol (Copenh) 117: 7-12.

57. Laurberg P, Cerqueira C, Ovesen L, Rasmussen LB, Perrild H, et al. (2010) lodine intake as a determinant of thyroid disorders in populations. Best Pract Res Clin Endocrinol Metab 24: 13-27.

58. Laurberg P, Andersen S, Carlé A, Karmisholt J, Knudsen N, et al. (2011) The TSH upper reference limit: where are we at? Nat Rev Endocrinol 7: 232-239.

59. Mariotti S (2005) Thyroid function and aging: do serum 3,5,3'-triiodothyronine and thyroid-stimulating hormone concentrations give the Janus response? J Clin Endocrinol Metab 90: 6735-6737.

60. Forti P, Olivelli V, Rietti E, Maltoni B, Pirazzoli G, et al. (2012) Serum thyroidstimulating hormone as a predictor of cognitive impairment in an elderly cohort. Gerontology 58: 41-49.

61. Gan EH, Pearce SH (2012) The thyroid in mind: cognitive function and low thyrotropin in older people. J Clin Endocrinol Metab 97: 3438-3449.

62. Resta F, Triggiani V, Barile G, Benigno M, Suppressa P, et al. (2012) Subclinical hypothyroidism and cognitive dysfunction in the elderly. Endocr Metab Immune Disord Drug Targets 12: 260-267.

63. Yeap BB, Alfonso H, Chubb SA, Puri G, Hankey GJ, et al. (2012) Higher Free Thyroxine Levels Predict Increased Incidence of Dementia in Older Men: The Health In Men Study. J Clin Endocrinol Metab

64. Zhang N, DU HJ, Wang JH, Cheng Y (2012) A pilot study on the relationship between thyroid status and neuropsychiatric symptoms in patients with Alzheimer disease. Chin Med J (Engl) 125: 3211-3216.

65. van Coevorden A, Laurent E, Decoster C, Kerkhofs M, Neve P, et al. (1989) Decreased basal and stimulated thyrotropin secretion in healthy elderly men. J Clin Endocrinol Metab 69: 177-185.

66. Barreca T, Franceschini R, Messina V, Bottaro L, Rolandi E (1985) 24-hour thyroid-stimulating hormone secretory pattern in elderly men. Gerontology 31: 119-123.
67. Herrmann J, Rusche HJ, Berger M, Krüskemper HL (1975) Thyroid function and triiodothyronine and thyroxine kinetics in rabbits immunized with thyroid hormones. Acta Endocrinol (Copenh) 78: 276-288.

68. van Coevorden A, Mockel J, Laurent E, Kerkhofs M, L'Hermite-Balériaux M, et al. (1991) Neuroendocrine rhythms and sleep in aging men. Am J Physio 260: E651-661.

69. Dayan CM, Saravanan P, Bayly G (2002) Whose normal thyroid function is better--yours or mine? Lancet 360: 353.

70. Bianco AC, Salvatore D, Gereben B, Berry MJ, Larsen PR (2002) Biochemistry, cellular and molecular biology, and physiological roles of the iodothyronine selenodeiodinases. Endocr Rev 23: 38-89.

71. INADAM, KOSHIYAMAK, TORIZUKAK, AKAGI H, MIYAKE T (1964) CLINICAL STUDIES ON THE METABOLISM OF 131-I-LABELED L-THYROXINE. J Clin Endocrinol Metab 24: 775-784.

72. Sawin CT, Geller A, Kaplan MM, Bacharach P, Wilson PW, et al. (1991) Low serum thyrotropin (thyroid-stimulating hormone) in older persons without hyperthyroidism. Arch Intern Med 151: 165-168.

73. Goichot B, Sapin R, Schlienger JL (2009) Subclinical hyperthyroidism: considerations in defining the lower limit of the thyrotropin reference interval. Clin Chem 55: 420-424.

74. Fatourechi V (2007) Upper limit of normal serum thyroid-stimulating hormone: a moving and now an aging target? J Clin Endocrinol Metab 92: 4560-4562.

75. Gussekloo J, van Exel E, de Craen AJ, Meinders AE, Frölich M, et al. (2004) Thyroid status, disability and cognitive function, and survival in old age. JAMA 292: 2591-2599

76. Atzmon G, Barzilai N, Hollowell JG, Surks MI, Gabriely I (2009) Extreme longevity is associated with increased serum thyrotropin. J Clin Endocrino Metab 94: 1251-1254.

77. Melmed S, Nademanee K, Reed AW, Hendrickson JA, Singh BN, et al. (1981) Hyperthyroxinemia with bradycardia and normal thyrotropin secretion afte chronic amiodarone administration. J Clin Endocrinol Metab 53: 997-1001.

78. Bremner AP, Feddema P, Leedman PJ, Brown SJ, Beilby JP, et al. (2012) Agerelated changes in thyroid function: a longitudinal study of a community-based cohort. J Clin Endocrinol Metab 97: 1554-1562.

79. Tietz NW, Shuey DF, Wekstein DR (1992) Laboratory values in fit aging individuals--sexagenarians through centenarians. Clin Chem 38: 1167-1185.

80. Magri F, Muzzoni B, Cravello L, Fioravanti M, Busconi L, et al. (2002) Thyroid function in physiological aging and in centenarians: possible relationships with some nutritional markers. Metabolism 51: 105-109.

81. Atzmon G, Barzilai N, Surks MI, Gabriely I (2009) Genetic predisposition to elevated serum thyrotropin is associated with exceptional longevity. J Clin Endocrinol Metab 94: 4768-4775.

82. Rozing MP, Houwing-Duistermaat JJ, Slagboom PE, Beekman M, Frölich M et al. (2010) Familial longevity is associated with decreased thyroid function. J Clin Endocrinol Metab 95: 4979-4984.

83. Buffenstein R (2005) The naked mole-rat: a new long-living model for human aging research. J Gerontol A Biol Sci Med Sci 60: 1369-1377.

84. Buffenstein R, Pinto M (2009) Endocrine function in naturally long-living small mammals. Mol Cell Endocrinol 299: 101-111.

85. Heinzel A, Kley K, Mueller HW, Hautzel H (2012) A comparison of rh-TSH and thyroid hormone withdrawal in patients with differentiated thyroid cancer: preliminary evidence for an influence of age on the subjective well-being in hypothyroidism. Horm Metab Res 44: 54-59.

86. van den Beld AW, Visser TJ, Feelders RA, Grobbee DE, Lamberts SW (2005) Thyroid hormone concentrations, disease, physical function, and mortality in elderly men. J Clin Endocrinol Metab 90: 6403-6409.

87. Maugeri D, Salvatore Russo M, Carnazzo G, Di Stefano F, Catanzaro S, et al. (1996) Altered laboratory thyroid parameters indicating hyperthyroidism in elderly subjects. Arch Gerontol Geriatr 22: 145-153.

88. Maugeri D, Speciale S, Santangelo A, Motta M, Panebianco P (1999) Altered laboratory thyroid parameters in elderly people. J Endocrinol Invest 22: 37

89. Maugeri D, Russo MS, Di Stefano F, Receputo G, Rosso D, et al. (1997) Thyroid function in healthy centenarians. Arch Gerontol Geriatr 25: 211-217. 